\title{
Innovation Capability: From Technology Development to Transaction Capability
}

\author{
Paulo Antônio Zawislak', André Cherubini Alves², Jorge Tello-Gamarra ${ }^{3}$, Denise Barbieux4, \\ Fernanda Maciel Reichert ${ }^{5}$
}

\begin{abstract}
The firm's role, besides producing goods and services, is to promote technological change and innovation. While academic research on technological capabilities has led to a better understanding of the process of technical change itself, there is no consensus on the ultimate definition of innovation capability. The purpose of this paper is to present a framework for innovation capability. This is formed by four key capabilities (technology development, operations, management and transaction) that enable firms to reach Schumpeterian profits. Given that the study is characterized as a theoretical paper, methodologically is supported on an extensive literature review. Our main findings can be summed up in three aspects: (I) every firm has all four capabilities; none of them are null; (2) to be innovative, at least one of the firm's capabilities must be predominant; (3) any firm, when established, is primarily technological or transactional, in a second stage, operational or managerial.
\end{abstract}

Keywords: operations capability; management capability; technology development capability; transaction capability; innovation capability.

Management School, Federal University of the State of Rio Grande do Sul (EA/UFRGS) Rua Washington Luiz, 855 Centro. Porto Alegre - RS. Postal Code: 90.0 10-460. +55 5I 33083536. (Corresponding authors).

E-mail: 'paz@ea.ufrgs.br, ${ }^{2}$ acalves@ea.ufrgs.br, ${ }^{3}$ jorgetellogamarra@gmail.com, ${ }^{4}$ dedsbar@terra.com.br, ${ }^{5}$ fernandareichert@yahoo.com

ISSN: 07 I8-2724. (http://www.jotmi.org)

Journal of Technology Management \& Innovation (c) Universidad Alberto Hurtado, Facultad de Economía y Negocios. 


\section{Introduction}

Innovation as source of competitive advantage for the firm is a consolidated issue in the literature. This is typically achieved when firms possess or develop their technological capabilities (Lall, 1992; Bell and Pavitt, 1995; Kim, 1999;Afuah, 2002; Reichert et al., 201 I). However, one matter that remains pending in this research area is: why not all firms that invest on their technological capability are innovative? Or why other firms that do not invest so much in that may have innovative performance? The answer to these questions can be found in a meta-capability called innovation capability.

The innovation capability as a new field of study is attracting interest from many scholars (e.g. Guan and Ma, 2003; Wang et al., 2008; Yam et al., 20 I I; Forsman, 20 I I). However, despite these important advances, there is still a lack of consensus among academics. To help overcome the shortcomings in innovation studies and particularly in the innovation capability concept, this paper aims to identify and analyze the four building blocks of this capability: technology development capability, operations capability, management capability, and transaction capability.

The technology development capability of the firm leads to technical change that allows for a successful innovation process. Once a new product has been thought out, the firm needs to produce it on a commercial scale. This is possible with the operations capability, which materializes the product created by the technology development capability. Besides, any firm aiming at obtaining Schumpeterian extraordinary profits needs transaction capabilities. Without them, there would be a gap between promoting technical change and obtaining positive performance on the market. The responsible for integrating these three capabilities (technology development, operations and transaction) is the management capability. They coordinate the work done by other capabilities.

This paper enlightens these different capabilities, their boundaries, types of activities and, specifically defines innovation capability. The innovation capability can be seen as an overall capability encompassing the ability to absorb, to adapt and to transform a given technology into specific management, operations and transaction routines that can lead one firm to Schumpeterian profits, i.e., innovation.

In section 2 we discuss the firm by combining transaction costs and resource-capability based view theories. Next, we explain the innovation capability and present a framework with the four capabilities and its interconnections with the firm, organization and enterprise. In section 4 we make a discussion on the framework we developed. Finally, we present our conclusions.

\section{The firm}

We part from two theoretically intense but often disconnected research approaches of the firm. One presents the firm as a collection of resources, knowledge, experience, skills and routines (Penrose, 1959; Richardson, 1972; Nelson and Winter, 1982; Chandler, 1992). The other deals with the view of the firm as a nexus of treaties working under certain limits and according to certain governance structure (Coase, 1937; Demsetz, 1968; Williamson, 1985).

For Langlois (2007), these views are complementary. Transaction cost theory proposes that there are some costs because of the natural limitations of knowledge and information, and capability theory insists that those limitations of knowledge and information are the key to understand everything an organization does (Langlois and Foss, 1999). Thus, the firm should be viewed as an agent of transaction following a governance structure, as well as an agent of production that has specific knowledge and skills.

In a broad-sense, the firm is the technical-economic agent that produces goods and services and transacts in the market by operating within a cost-minimizing organizational structure that should change over time by both internal and external forces. To continue operating in a chosen environment, the firm must produce some different solution, which is recognized as such by the consumer.

This definition of the firm encompasses two important aspects. First, the firm only exists because it is able to deliver value to the market. Second, it does so, through a technical structure called 'organization'. There are many names to refer to the firm such as, company, corporation, organization, enterprise, business and so on. We make a distinction between three major terms: firm, organization and enterprise.

\section{I. Firm, organization and enterprise}

In the concrete world, the firm is commonly viewed as the business enterprise, in other words, the legal-institutional entity allowed to produce and sell goods and services. The enterprise can legally exist, but to be a firm, it has to "deliver the most utility to ultimate consumers at the lowest cost" (Langlois, 2003, p. 355). To accomplish that task, the enterprise has to distinguish two interrelated systems: the technology of production and the organizational structure that directs production. In a stricto sensu definition, the firm is the transaction-economic agent that carries out the production and sales of goods and services within the expectations of another agent, the consumer. Goods and services should fulfill a market gap (demand). 
Since the firm is a repository of knowledge (Winter, 1991), it will transfer its goods and services to consumers to fulfill that gap. In an economic system, this is done through 'transaction'. The sine qua non condition for the enterprise to become a firm is to have a specific knowledge that can be efficiently applied to bring valuable solutions (goods and services) with selling potential.

In that sense, firms should translate specific knowledge into an efficient, well arranged set of organized and structured procedures, decision rules, specific skills, and products to fulfill the knowledge gap in the market. In other words, the firm requires an 'organization' to transform the specific knowledge into selling products. The organization is the technical structure responsible for the availability of resources (human, materials, energy, and equipment) according to a given technology (knowledge, methods and practices) for the production and sale of goods and services with value. The organization is an indirect but necessary consequence of any firm. There is no firm without an organization.

However, it is important to make a fine distinction: neither the enterprise nor the organization is the economic agent. The only economic agent is the firm. It is the firm that creates value and profit in the strict sense.

The firm can decide whether to turn new technological solutions into new operations or to manage new transactions within its current technological state of knowledge. These two types of decision are respectively the functions of the Schumpeterian entrepreneur (Schumpeter, 1942) and the Coasean coordinator (Coase, 1937).

\subsection{The entrepreneur and the coordinator}

The question made by Coase (1937) 'Why do firms exist?' is only partially answered by transaction costs economics. According to Coase (1937), the scope of the firm is determined at the margin. It will expand the number of internal activities until the costs of internalizing one more transaction just balances out the costs of an equivalent transaction on the market. If the firm is the reason for the existence of the organization and the organization is what 'gives life' to the firm, by allowing it to do a better job than the market in reducing transaction costs, some questions still remain such as: 'Why the firm came into being in the first place?' or 'How does it perpetuate itself over time?'. To answer these questions, one should promote a "meeting" between Coase and Schumpeter.

Coase's (1937) coordinator is not necessarily an agent of change, but of efficiency. His role is to choose according to market expectations the best generic mode to organize the production of any given product under the hierarchical structure of a firm.
Schumpeter's (1942, p. 132) entrepreneur's function is:“...to reform or revolutionize the pattern of production by exploiting an invention or, more generally, an untried technological possibility for producing a new commodity or producing an old one in a new way". Schumpeter's entrepreneur is a sort of breaker of constraints. "His new combination is based on novel premises, but not on any premises that he might fancy: it is the imagined, deemed possible" (Loasby, 1999, p.63). In this sense, the entrepreneur goes further than the coordinator: he changes the efficiency pattern.

Therefore, the combination of Coase's and Schumpeter's view upon the entrepreneur-coordinator function helps to describe the nature of the firm as it actually is: an economic agent that promotes technological change and innovation in order not only to reduce costs (efficiency), but to increase revenues by making it more efficient than the market.

This is the same reasoning that Penrose (1959) uses in distinguishing the two functions. She characterizes the coordination as a maintenance role performed by managerial services focused on organizational continuity, while the entrepreneur is concerned with changes in knowledge, resources and structures.

Lazonick (1991, 1992) differentiate these functions in terms of adaptive and innovative strategy. Through the adaptive strategy, the entrepreneur-coordinator chooses to keep the value-creating capabilities inherited from the past by just trying "to squeeze every last bit of potential profit out of their businesses by employing additional variable factors of production up to the point where marginal cost, just equals revenue" (Lazonick, 1991, p. 172). This strategy may be profitable in the short-run, but in the long run it will make the firm vulnerable to the innovative strategies of competitors. Therefore, the entrepreneur-coordinator should choose the innovative strategy in order to renew the value-creating potential of his firm.

If our assumption on the dependence between the firm and the organization is true, no production or transaction of a specific knowledge will ever happens without the coupled interpretation of the entrepreneur-coordinator. The entrepreneur-coordinator is, therefore, the very essence of the innovative process and thus the existence of the enterprise. $\mathrm{He}$ is able, at the same time, to perceive new ventures, to use new knowledge, to manage new combinations, to operate new process, and to sell new products that are recognized as more valuable than others by the market. More valuable recognized ventures are: innovation.

By combining those ideas surrounding the definitions of the firm, the organization and the enterprise with the discussion over the Coasean coordinator and the Schumpeterian 
entrepreneur, we draw our capability based-model of the innovation capability.

\section{Innovation Capability}

To exist and to thrive, every firm must have some specific capabilities. Different authors have initiated the studies on capabilities under different labels such as human resources (Penrose, 1959; Barney, 1991), distinctive competencies (Selznick 1957; Snow and Hrebiniak, 1980), specific skills (Richardson, 1972), invisible assets (Itami and Roehl, 1987), repertoire of routines (Nelson and Winter, 1982), core competences (Prahalad and Hamel, 1990), absorptive capacity (Cohen and Levintal, 1990), organizational capabilities (Chandler, 1992; Dosi et al., 2000), technological capabilities (Lall, 1992), and marketing capability (Kotabe, et al., 2002).All these labels refer to specific capabilities that the firm creates and uses strategically in order to identify market gaps to be filled with new offerings of value.

These studies have been important to the understanding of the firm; however, there is no agreement on what are the capabilities that ensure survival and superior performance, nor a consensus on the ultimate definition of innovation capability.
Lall (1992) stressed the power of technological capability as the way firms absorb, process, create, change and generate feasible technical applications (new technology, new process, new products, new routines) within the knowledge frontier. However, one missing link seems to be forgotten: how seldom all this technological effort really turns into positive performance and recognized economic outcome. In other words, if a firm has developed technological capability, it does not necessarily mean that it will consequently have innovation capability'.

There are many studies on innovation capability aiming at developing the concept itself, as well as trying to identify the capabilities needed that allow the firm to innovate (Guan and Ma, 2003;Wang et al., 2008; Zawislak, et al., 2009; Yam et al., 20 I I; Forsman, 20 I I; Alves et al, 20I I). However other contributions are still needed to consolidate this new area of research.The innovation capability is understood as both the technological learning process from the firm translated into the technology development and operations capabilities, as well as the managerial and transactional routines represented by the management and transaction capabilities. The integration between these four capabilities effectively promotes innovation which creates competitive advantages. Table I presents the innovation capability as a meta-capability embedded in four different complementary capabilities.

\begin{tabular}{|l|l|}
\hline Capability & Definition \\
\hline $\begin{array}{l}\text { Technology Development } \\
\text { capability }\end{array}$ & $\begin{array}{l}\text { The ability that any firm has to interpret the current state of the } \\
\text { art, absorb and eventually transform a given technology to create } \\
\text { or change its operations capacity and any other capability aiming } \\
\text { at reaching higher levels of technical-economic efficiency. }\end{array}$ \\
\hline Operations capability & $\begin{array}{l}\text { The ability to perform the given productive capacity through the } \\
\text { collection of daily routines that are embedded in knowledge, skills } \\
\text { and technical systems at a given time. }\end{array}$ \\
\hline Management capability & $\begin{array}{l}\text { The ability to transform the technology development outcome into } \\
\text { coherent operations and transaction arrangements. }\end{array}$ \\
\hline Transaction capability & $\begin{array}{l}\text { The ability to reduce its marketing, outsourcing, bargaining, logis- } \\
\text { tics, and delivering costs; in other words, transaction costs. }\end{array}$ \\
\hline
\end{tabular}

Table I

Definition of Capabilities

\footnotetext{
'The definition of innovation is quite confusing. One can keep the Schumpeterian point of view of successful business ventures that necessarily gives to the entrepreneur extraordinary profits. Other can consider a more technical definition, such as those that advocate that any novelty that is brought to the market should already be considered an innovation. In this paper, we follow a Schumpeterian tradition. This means that an existing technological capability is not a sufficient condition to consider any firm to be innovative. In our assumption, to be innovative the firm should understand and lay its strategies over the innovative capability.
}

ISSN: 07 I8-2724. (http://www.jotmi.org)

Journal of Technology Management \& Innovation (c) Universidad Alberto Hurtado, Facultad de Economía y Negocios. 


\section{I Technology Development capability}

Since the early 1980's, technological capabilities have been defined as both:"the ability or proficiency to make effective use of technological knowledge" (Westphal, Kim and Dahlman, 1985, p. I7I) and as the capabilities needed to generate and manage technical change (Bell and Pavitt, 1995). According to Dutrénit (2000) technological capabilities inheres not in the knowledge that a firm possesses, but in the way that this knowledge is used and in the proficiency of its use in production, investment and innovation. "If a firm is unable by itself to decide on its investment plans or selection of equipment processes, or to reach minimum levels of operating efficiency, quality control [...] it is unlikely to be able to compete effectively in open markets" (Lall, 1992, p.168). However, "the technological capabilities needed to generate and manage technical change include skills, knowledge, and experiences that often (but not always) differ substantially from these needed to operate existing technical systems [...]" (Bell and Pavitt, 1995 p.78).

In this sense we differentiate the technological capability necessary to make effective use of the technology as operations capability (refer to next section); and the technological capability used to manage and generate technological change as the technology development capability.

The technology development capability allows the firm to choose and to use technology with strategic purposes (Gomel and Sbragia, 2006; Rush et al., 2007), to create new methods, process and techniques (Afuah, 2002), and, mostly, to offer new products (Zhou and Wu, 2010 p.557). The basic assumption is that technology development capability is a result from the learning process through which firms internalize new knowledge to produce technological change, consequently new process and products. It involves movements of the production function rather than along it (Lall, 1992). This learning process can involve acquisition, imitation, adaptation, modification and/or the development of a new set of knowledge and technical systems for internal use. The result of this process should be potential goods and services with new technical patterns for the firm. Those are, after all, the technological innovations.

More important than simple technological change, the perspective of providing innovative solutions to the market is the major goal of the firm's technology development capability. However, a capability to efficiently operate the technology in order to produce tradable goods and services is also needed. This is the operations capability.

\subsection{Operations capability}

"Every organization, no matter what sector, has an operations function (even if it is not called by this name) because every organization produces some mix of goods and services" (Slack and Lewis, 2008, p.I). Here we consider the ability to use technology as operations capability. Activities such as quality control, preventative maintenance, work flow and inventory control, mentioned by Lall (1992, p.167) as part of the technological capabilities, actually fall under the operations capability category. Thus, it is what the firm really does given what it knows.

Jacobides and Hitt (2005) state that capabilities are driven by the firms' knowledge of the production process. They say this knowledge "is developed by a path-dependent process of complementary investment and learning by doing" (Jacobides and Hitt, 2005, p. I2 I2); as well as shaped by a series of contingencies which firms face in their operations. The authors suggest that even if the primary resources were supplied homogeneously, different firms are likely to develop different processes, and therefore, to present different productive capabilities.

Beyond the mere production of goods and services, operations capability should be concerned with the alignment of the production strategy with the firm's competitive strategy and goals (Skinner, 1969). Operations capability involves the occupation of the firm's production capacity aiming at the necessary productive output it should achieve in a given period of time. The operations capability is a result of the selection of competitive priorities in order to take advantage of things like: low cost, quality, delivery time, responsiveness, flexibility (Skinner, 1974; Hayes and Pisano, 1994), degree of product or service standardization, size of product mix carried within the firm, volumes required (Ward, et al. 1998; Hayes et al. 2005) as well as production lead-time and the ability to concretely attend technological innovation required by the market (Hayes et al., 2005).

The firm should implement a production system which better adapts to its products, its capacity, and ultimately, to its customers' needs and satisfaction. What a firm aims in relation to its operations capability is to have the continuous ability to reduce costs, to improve quality, to get more flexibility and to have responsiveness.

Both technology development and operations capabilities play important roles within the firm. The first is responsible for creating new products, while the latter enables the manufacturing these products on a commercial scale. However, for that these capabilities to work in a synchronized manner, every firm requires a capability to integrate and coordinate them, that is, they need management capability.

ISSN: 07I 8-2724. (http://www.jotmi.org)

Journal of Technology Management \& Innovation (c) Universidad Alberto Hurtado, Facultad de Economía y Negocios. 


\subsection{Management capability}

The emergence of the big enterprises, in the beginning of the twentieth century, brought much interest around the roles and functions of managers (Fayol, 1949; Mintzberg, 1973; Barnard, 1966). With the application of scientific knowledge into the production systems, vertical integration of whole supply chains and the active 'visible hand' of management, firms were able to plan and co-ordinate transactions more efficiently than if they were carried out through the 'invisible hand' of the market (Taylor, 191 I; Schumpeter, 1942; Williamson, 1985; Chandler, 1977).

The main advantage of the formal managerial organization is the ability to integrate and combine productive capabilities of human and physical resources. It can contribute to the firm's capability to achieve higher levels of resource utilization and the ability to anticipate shortages (Lazonick, 1992). Overall, the management capability maintains a smooth flow of information and outputs to reach higher rates of efficiency ${ }^{2}$.

"Managerial services, therefore, have economic value by virtue of organizing and controlling resources in systematic and cohesive ways and are constitutive of firms" (Whitley, 1989). However, it does not follow the same pattern as operational routines (Stamp, 1981; Whitley, 1989). If capabilities can be explained by a set of routines embedded in applied knowledge (technology), management capability requires a more generalist repertoire to take action through choice and decision where technology fails to be perfectly routinized. In order to cope with often unpredictable circumstances, management capability needs a wide range of skills to be applied flexibly in problem solving (Langlois, 2003).

Management capability not only reduces the costs imposed by uncertainty, but also is dynamic and evolving, ideally concerned with the maintenance of administrative structures and the improvement of resource coordination and use, combining continuity with innovation (Whitley, 1989).

The management capability, however, will vary according to the degree of asset specificity of the technology involved and the costs to organize the aforementioned arrangement. For each level of asset specificity, the firm should build its own management system and be capable to change it over time. Every firm has its limits (Coase, 1937; Penrose, 1959), and to overpass them, not only technology must be enhanced, but managerial routines should be enlarged to deal with one more operation and one more transaction. In doing that, the firm is surely innovating.

${ }^{2}$ Somehow, one can consider management as the former neoclassical definition of the firm: to ensure the best resource arrangement given the technology and its production function.
With a mastered technology and settled managerial routines, any firm should, at once, put it to work. This implies on the capability to efficiently operate the technology in order to produce tradable goods and services. Transacting in the market requires that the firm has a set knowledge, abilities and routines, that is, transaction capability.

\subsection{Transaction capability}

Once a technological solution has been developed, every firm should be able to do whatever it takes in order to favor the transaction, in other words, to sell it. The sales are facilitated through what we call transaction capability ${ }^{3}$. The transaction capability is everything that a firm actually does to reduce its marketing, bargaining and delivering costs, in other words, to reduce transaction costs.

A growing literature indicates the existence of this capability (Argyres, 1996; Hodgson, 1998; Langlois and Foss, 1999; Williamson, 1999; Mayer and Argyres, 2004; Jacobides and Winter 2005; Mayer and Salomon 2006; Argyres and Mayer 2007,Argyres, 20 I I; Nogueira and Bataglia, 20 I2), but significant progress still needs to be done.

Mayer and Salomon (2006) have proposed the concept of governance capability, which is defined as the capabilities that reduce the costs imposed by contractual risk. They also argue that technological capability can improve firms' ability to manage their transactions. Thus, a firm that can improve its technology development capability has more chances to improve its governance capabilities in comparison to its competitors.

Once a firm is able to produce something that is perceived as valuable when compared to similar existing solutions of competitors, it should be able to transact it in the market. Since every firm uses, manages and operates a given technology with the explicit goal of making economic positive returns, it should have a specific capability to trade its products.

Like any other capability, it needs to be created, developed and changed. In this process learning plays, once again, a key role. In this sense, learning to contract (Mayer and Argyres, 2004) develops the capability to design contracts (Argyres and Mayers, 2007). Firms that align their terms of contracts, the transaction attributes and the capabilities will have experience in more successful contracts than those firms that misaligned them (Argyres and Mayers, 2007). Alternatively, if

${ }^{3}$ This concept was somehow used by Teece $(1986,2006)$ and Teece et al. (1994). However, they do not indicate characteristics, scope and the necessity of this capability in order to understand the nature of the firm. 
the firm's advantage can be achieved using the technology development capability (to create new products), operations capability (to produce these products more efficiently) and management capability (to maintain all areas of the firm tuned and running), the development of its transaction capability will then help to expand this advantage. Transactional innovation is thus another innovative issue.

In order to better understand the firm's successful performance through innovation, we use a framework that aggregates all four complementary capabilities into one, the innovation capability.

\subsection{The innovation capability framework}

Innovation can emerge from any one of the complementary capabilities. If technological innovation is perhaps the most evident and charming type of innovation, not all firms are able to technologically innovate. For example, companies in commodity markets will mostly follow technical constraints, such as production process and product mix. However, if they are trading, it is because they surely present some other advantage. It is our assumption that this advantage, whenever it is not on technology development, is related to management, operations or transaction capabilities, and it can be respectively translated into efficiency, productivity or marketing gains.

Our framework presents the idea that every firm starts by having a special knowledge advantage that supposedly can be translated into a technology that has value on market. If the firm exists to transact what it 'knows how' to do, and this applied 'know-how' corresponds to the firm's specific technology, the firm transacts technology. From this point of view, both technology development and transaction capabilities are the essence of the firm, aiming at finding a new knowledge that can be applied in effective solutions to existing and identified market gaps.

The problem is that the potential technological solution to be translated into an operational arrangement must be efficiently managed to guarantee the delivery of the expected outcome. Management of technology is the major connecting competence between technology development and management capabilities. Technology development capability provides 'development' as the result from the learning process through which firms internalize new knowledge to produce technological change and, consequently, new processes and products. This process involves search routines and the ability to change from one stage to another through the entrepreneur function which consists of creating and re-creating the operations once new knowledge is absorbed and the imagined is deemed possible.

The concrete applied technological solution (presented here in terms of a specific process and its resulting products) is brought to light by the operations capability. It uses already stabilized technology with established routines and procedures. Once the operation is in fact stable, other indirect procedures, routines and decision rules which constitute the organization, should be achieved by the combination of the management with the operations capabilities. This is related to the control effort which guarantees the operations.

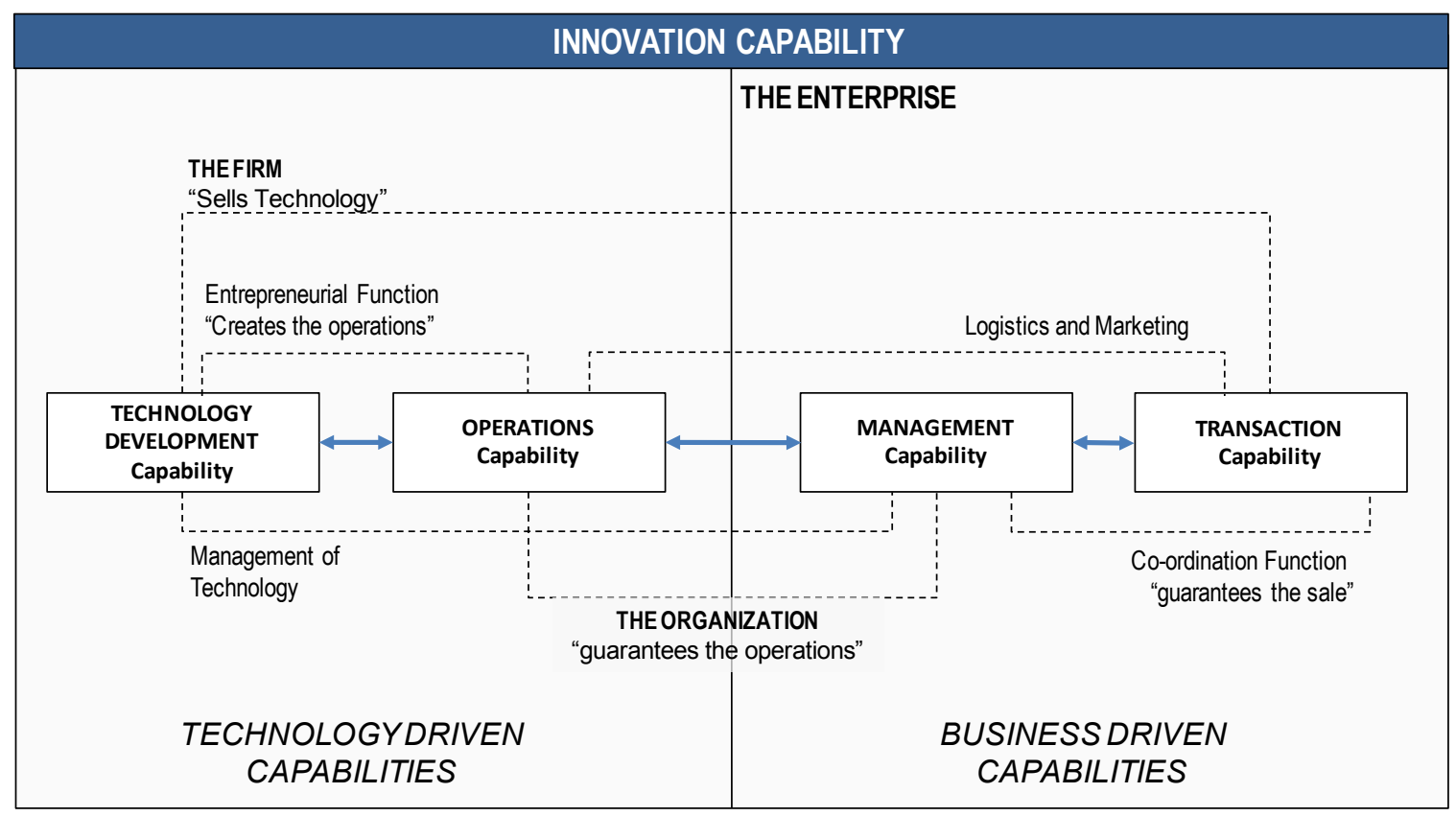

Figure I

ISSN: 07 I8-2724. (http://www.jotmi.org)

Journal of Technology Management \& Innovation (c) Universidad Alberto Hurtado, Facultad de Economía y Negocios. 
Although a technology must in fact be turned into operations - since the entrepreneurial creation of a productive solution aims to do so in order to get products done - it is the transaction capability that is responsible for connecting the firm to the market. In most of the times, this capability provides guidance through different commercial activities (customer service, marketing, logistics) to where the technological change must follow.

The coordination function is the link between the management capability and transaction capability in which procedures, routines and decision rules aim at guaranteeing sales. In sum, the firm's innovation capability is the ability to provide new valuable solutions validated by the market, wherever it came from. Figure I summarizes the framework for innovation capability.

In order for a firm to obtain Schumpeterian extraordinary profits, the transaction capability must be integrated with the others. The integration of these capabilities is what 'gives life' to the firm. Without the transaction capability, there would be a gap between promoting technical change and obtaining positive performance on the market. Although the technology development capability of a firm is an important component for the innovation process, it is insufficient in explaining how any firm turns internal technological invention into market transaction and innovation. This framework offers possible explanations not only to the firm's existence but for its origins and differences between firms across different economic sectors.

\section{Propositions}

Every firm, in essence, develops, makes, manages and sells technical solutions. This does not happen by accident. Instead, it is a deliberate act as it implies the existence of an entrepreneur-coordinator to identify a market gap (e.g. technological, marketing, locational, legal-institutional) to be filled with a specific knowledge based product. Somehow, every successful firm will have in its origins some specific knowledge that has made the difference, even if it was only once or for a short period.

Once identified the gap, the firm translates its knowledge and skills into organized operations and transactions. The firm exists through its capabilities that are put together to deliver utility to consumers. These are core activities that represent the firm's 'know-how' of developing, producing, managing, and transacting new solutions.

The value delivered is a function of these four capabilities combined. This does not imply necessarily formal capabilities; informal structures of work can follow different levels of capabilities. A simple idea, informally managed to work under a minimum operational structure can be a market success if, for example, the geographic location is exclusive.

For example, the technology development capability is crucial but not sufficient to ensure operations efficiency or management integration of all areas of the company or even the transaction with suppliers and customers. Therefore, the technology development capability must be complemented to some extent with other capabilities.

Along the same lines, we also can identify that firms whose operations capability is much more developed than their competitors, seek to strengthen their other three capabilities. This may explain why some firms that focus their efforts on a single capability at the expense of others fail in the market.

The origin of the firm can begin with the application of a technology-based knowledge to result in a prototype. However, this does not guarantee its existence. Before that, the prototype must be manufactured at the lowest possible cost, with the support of a managerial structure and eventually be transacted. Considering the arguments of the discussion, the following proposition is made:

\section{Proposition I: Every firm has all four capabilities. None of them are null.}

Considering the different complementary capabilities of the firm, it is reasonable to try to identify which capability best defines the success of a firm. This intriguing question has led to the creation of a body of theory that argues that the success of firms comes from the development and implementation of, essentially, a single capability; for example, the technology development capability (Lall, 1992; García-Muiña and Navas-López, 2007) or operations capability (Ward et al., 1998). In this proposal, we believe that the superior performance of firms is a consequence of the predominance of one of the capabilities, but which does not imply that the firm does not have the others.

A firm is always created from the combination of the four capabilities (technology development, operations, management and transaction). Yet to be an innovative firm, at least one of them should be above the market average. The firm will be innovative in the presence of a "higher order capability'.

The innovative capability is thus, the result of some dominant capability that is complemented with the other ones. In this context, the innovative firm may be of four types: technological, transactional, managerial or operational. 
Technology-based firms are those in which technology development capability is prevalent - but they always require some degree of operations capability. Here we can exemplify with the case of technology incubators. These firms often begin operating with support from some government institution or university, but seek somehow to supply its transaction capability gap through this decision which, among other things, grants them access to the organizational structure and transaction capability to sell its technological solution. The Sentinelle Medical Inc. and Visual Sonics are two technology-based firms that fit this profile. Initially, these companies were born with spinoffs in the Sunnybrook Research Institute (SRI, 20II) in Canada. Once incubated, companies have developed the other capabilities, including transaction and management, making them able to work with greater autonomy.

On the opposite side, a firm that has well developed transaction capability, but with a technology development capability that has been relatively weaker, is Coca Cola. The company is the result of applying technology development capability that led to the formula of Coca Cola syrup (Teece, 1986). Nowadays, the firm continues with its original formula and uses the power of their brand to create new extensions (Zhang and Sood, 2002), advertising campaigns, and regional outsourced producers enabling it to continue being successful. No doubt Coca Cola is innovative, but its advantage is in terms of its transaction capability. Nonetheless, Coca Cola has its operations capability in order to produce the minimum amount of its syrup that protects the secret of the product. Currently, it also has some technology development capability to develop alternatives to compete with other products (i.e. Coca-Cola light), and to do that, it needs to reach a certain level of efficiency; therefore it must have management capability. However, it is prevalent their transaction capability.

For a company in a traditional and mature industry, such as the iron and steel sector - where prices are well defined by the market, where most of the knowledge about the processes is already dominated and few new improvements are to be developed - it is reasonable to think that the big secret will be its management capability. The Brazilian company Gerdau is an example of management oriented capability. With its growth strategy mostly based in mergers and acquisitions overseas, it had to learn and to change itself in order to manage its operations in the different countries and cultures. This doesn't mean the company does not have a minimum of technology development capability to guarantee the quality of product according to the customer requirements. And it must also have a certain transaction capability to be able to bargain in a worldwide market, dominated by players such as Arcelor Mittal or Nippon Steel.
Micro-electronics firms that are outsourced in China by Apple, for example, fit in the operations capability profile. In this example, the firm only exists because Apple's technology development capability identifies on the operations capability of the outsourced firm the possibility to produce in a more efficient way than Apple itself. At the same time, the outsourced firm will need some technology development capability every time Apple launches a new product that will need to be produced in series. The outsourced firm will need to design a prototype and adjust the process. Also, to translate these adjustments into an efficient operation, it will need management capability. Finally, the simple fact that the companies negotiate with Apple, requires a minimum of transaction capability. Moreover, there are firms that have turned from the prevalence of operations capability. These are processes oriented and have managed to gain operational efficiency which guarantees them a competitive advantage. Technological innovation can be present in these firms, but they are not recognized for being great technological innovators. Also, they have transaction capability that allows them to transact faster and cheaper, but its production process in this differential with suppliers and the consumers.

These examples show that every firm will always have all four capabilities combined, but with different levels, which brings us to the second proposition:

\section{Proposition 2: To be innovative, at least one of the firm's capabilities must be predominant.}

It is important to note that this 'dominance' is not a static subject, but the types of capabilities that are prominent in a given time can be another one in the future. This evolution takes place mainly by the fact that first, firms are born as a result of a minimum of specific technology development capability since it has identified a market gap that can be filled only with the transaction capabilities.

However, firms realize they need to keep evolving to continue developing their capabilities according to new market demands. In this sense the third proposition is:

\section{Proposition 3:Any firm, when born, is primarily tech- nological or transactional, in a second stage, opera- tional or managerial.}

For example, firms that were innovative at the beginning due to the predominance of their technology development capability, as the market matures, may need to develop other capabilities. In this sense, we understand that there may be a migration of capabilities. The firm continues with some predominant innovative ability, but it has to enlarge its productive, management or even transaction capabilities. 
The second factor of evolution is due to the change triggered by the very firm that, regardless of market dynamics, the company might decide to migrate its efforts to other capabilities. . For instance, firms that have developed a technology development capability may decide to become predominant in operations. This migration of capabilities whether by market demand or within the firm, is a recurring action in every kind of market and like any strategic decision, is risky. To choose what capability and when to migrate predominantly depend on the ability of better processing information within the limits of rationality of economic agents (Simon, 1945).

\section{Conclusion}

In this paper we define firms and organizations based on their entrepreneurial and coordination functions. In doing that, we have developed our innovation capability model of the firm, which implies on some analytical issues.

First, the firm exists because of the difference of knowledge among the entrepreneur-coordinator and the consumer. Second, every firm has four capabilities (technology development, operations, management and transaction). Third, for a firm to perpetuate on the market, it is necessary to change its technological knowledge overtime. Finally, for a firm to innovate, its capabilities need to be specific and integrated so it can generate Schumpeterian profits. For this, we define the boundaries of these capabilities.

Innovation capability is the ability to absorb, adapt and transform a given technology into specific operational, managerial and transactional routines that can lead a firm to Schumpeterian profits, i.e., innovation. By doing so, a firm can perpetuate itself overtime.

For this, technology development capability is what the firm does to change what it knows, in other words, is to internalize new knowledge. The firm's development is based on this technological change process. To complete the innovation process, transaction capability is necessary, that is, its routines, processes and decision rules are such as to make the best choice to minimize transaction costs. To maintain and control all these process inside the firm, operations capability is the ability to perform the given productive capacity through the collection of daily routines that are embedded in knowledge, skills and technical systems at a given time. Finally, the management capability is the mechanism that the firm will transform the technological outcome into an efficient operational process.

What is important about the four capabilities that constitute the innovation capability is that each firm reveals something unique and of value to their markets.

\section{Acknowledgements}

The present study was carried out with the financial support of the Brazilian Government research funding agencies Research Foundation the State of Rio Grande do Sul (FAPERGS) and the Brazilian National Council for Scientific and Technological Development (CNPq).

\section{References}

ALVES, A, C., Zen, A, C., Padula, A. D. (20I I). Routines, Capabilities and Innovation in the Brazilian Wine Industry. Journal of Technology Management and Innovation. 20II, 6 (2), 128-I44.

AFUAH, A.N. (2002) Mapping technological capabilities into product markets and competitive advantage'. Strategic Management Journal, 23 (2), I7I-I79.

ARGYRES, N. (1996). Evidence on the role of firm capabilities in vertical integration decisions. Strategic Management Journal, 17 (2), I29-I50.

ARGYRES, N., Mayer, K. (2007). Contract design as a firm capability: an integration of learning and transaction cost perspectives. Academy of Management Review, 32 (4), 1060-1077.

ARGYRES, N. (20II). Using organizational economics to study organizational capability

development and strategy. Organization Science, 22(5), 2205-1I38.

BARNARD, C. (1966). The Functions of the Executive. Harvard University Press, Cambridge. First published in 1938.

BARNEY,J. (1991). Firm resource and sustained competitive advantage. Journal of Management, 17 (I), 99- 120.

BELL, M., Pavitt, K. (1995). The development of technological capabilities. Trade, Technology and International Competitiveness. Economic Development Institute of the World Bank, 69-100.

CHANDLER, Alfred D., Jr. (1977), The Visible Hand. Cambridge, Mass. and London, England: The Belknap Press of Harvard University Press.

CHANDLER, A. D. (1992). Organizational capabilities and the economic history of the industrial enterprise. Journal of Economic Perspectives, 6 (3), 79-100.

COASE, R. (1937). The nature of the firm. Economica, 4 (16), 386-405. 
COHEN,W., Levinthal, D. (1990). Absorptive capacity: a new perspective on learning and innovation. Administrative Science Quarterly, 35 (I), 128-152.

DEMSETZ, H. (1968). The cost of transacting. The Quarterly Journal of Economics. 82 (I), 33-53.

DOSI, G., Nelson, R.,Winter, S. (2000). Introduction:The Nature and Dynamics of Organizational Capabilities. In: Dosi, G., Nelson, R., Winter, S. (Eds.). The Nature and Dynamics of Organizational Capabilities. Oxford University Press, New York.

DUTRÉNIT, G. (2000). Learning and knowledge Management in the firm: from knowledge accumulation to strategic capabilities. Edward Elgar, Northampton, Ma. Reprinted 2003.

FAYOL, H. (1949). General and industrial management. London, Sir Issac Pitman \& Son.

FORSMAN, H. (20II). Innovation capacity and innovation development in small enterprises. A comparison between the manufacturing and service sectors. Research Policy, 40 (5), 739-750.

GARCÍA-MUIÑA F., Navas-López, J. (2007). Explaining and measuring success in new business: The effect of technological capabilities on firm results. Technovation, 27 (I-2), 30-46.

GOMEL M.M., Sbragia R. (2006). A capacitação tecnológica e o desempenho exportador da indústria brasileira de software: o papel dos investimentos em P\&D. Journal of Technology Management \& Innovation, I (3), 60-73.

GUAN, J., Ma, N. (2003). Innovative capability and export performance of Chinese firms. Technovation 23 (9), 737-747

HAYES, R. H., Pisano, G. P. (1994). Beyond world-class: The new manufacturing strategy. Harvard Business Review, 72 (I), 77-86.

HAYES, R.H., Pisano, G.P., Upton, D., Wheelwright, S. (2005). Operations, Strategy, and Technology: Pursuing the competitive edge. Hoboken:Wiley. (Brazilian translation)

HODGSON, G. (1998). Competence and contract in the theory of the firm. Journal of Economic Behavior and Organization, 35 (2), 179-210.

ITAMI, H., Roehl, T. (1 987). Mobilizing invisible assets. Harvard University Press, Cambridge.
JACOBIDES, M.G., Hitt, L. M. (2005). Losing sight of the forest for the trees? Productive capabilities and gains from trade as drivers of vertical scope. Strategic Management Journal, 26, I209-1227.

JACOBIDES, M.G.,Winter, S. (2005). The Co-Evolution of Capabilities and Transaction Costs: Explaining the Institutional Structure of Production. Strategic Management Journal, 26 (5), 395-4I3.

KIM, L. (1999). Building technological capability for industrialization: analytical frameworks and Korea's experience. Industrial and Corporate Change, 8 (I), I I I-I36.

KOTABE, M., Srinivasan, S.S., Aulakh, P. (2002). Multinationality and firm performance: The moderating role of R\&D and Marketing Capabilities. Journal of International Business Studies, 33 (I), 79-97.

LALL, S. (1992). Technological capabilities and industrialization. World Development, 20 (2), |65-186.

LANGLOIS, R.N. (2003). The Vanishing Hand:The Changing Dynamics of Industrial Capitalism. Industrial and Corporate Change, I2 (2), 35I-385.

LANGLOIS, R. N. (2007). The Dynamics of Industrial Capitalism:Schumpeter, Chandler, and the New Economy. The Graz Schumpeter Lectures 2004. London: Routledge.

LANGLOIS, R.N., Foss, N. (1999). Capabilities and governance: the rebirth production in the theory of economic organization. Kyklos, 52 (2), 20I-2I8.

LAZONICK, W. (1991). Business Organization and the Myth of the Market Economy. Cambridge University Press, New York.

LAZONICK,W. (1992). Business Organisation and Competitive Advantage: Capitalist Transformations in the Twentieth Century. In: Dosi, G., Giannetti, R., Toninelli, P.A. (Eds). Technology and Enterprise in a Historical Perspective, Oxford University press, Oxford, I19-163.

LOASBY, B. J. (1999). Knowledge, Institutions and Evolution in Economics. Londres: Routledge.

MAYER, K., Argyres, N. (2004). Learning to contract: Evidence from the personal computer industry. Organization Science, I5 (4), 394-4I0.

MAYER, K., Salomon, R. (2006). Contract design as a firm capability: an integration of learning and transaction cost perspectives. Academy of Management Review, 49 (5), 942-959. 
MINTZBERG, H. (1973). The Nature of Managerial Work. Harper \& Row, New York.

NELSON, R., Winter, S. (1982). An Evolutionary Theory of Economic Change. The Belknap Press of Harvard University Press, Cambridge, Ma.

NOGUEIRA A.C., Bataglia,W. (20I2). Transaction Costs and Organizational Competences: Explaining the Governance Structure for Manufacturing Stage. Journal of Technology Management \& Innovation, 7 (I), I59-I74.

PENROSE, E. (1959). The Theory of the Growth of the Firm. Oxford University Press, New York. 272p. Reprinted in 1995.

PRAHALAD, C., Hamel, G. (1990). The core competence of the corporation. Harvard Business Review, 68 (3), 79-9l.

REICHERT, F. M.; Beltrame, R. S; Corso, K. B.; Trevisan, M.; Zawislak, P. A. (20II). Technological Capability's Predictor Variables. Journal of Technology Management \& Innovation, $6(1), 14-25$.

RICHARDSON, G. (1972). The organization of industry. Economic Journal, 82 (327), 883-896.

RUSH, H., Bessant, J.; Hobday, M. (199I). Assessing the technological capabilities of firms: developing a policy tool. British Journal Management, v. 2, p. 4I-50.

SCHUMPETER, Joseph A. (1942). Capitalism, Socialism and Democracy. Harper, New York.

SELZNICK, P. (1957). Leadership in administration: a sociological interpretation. University of California Press, Berkeley and Los Angeles, Ca. Reprinted in 1984.

SIMON, H. (1945). Administrative Behavior. Free Press, New York. Reprinted in 1997.

SKINNER, W. (1969). Manufacturing: missing link in corporate strategy. Harvard Business Review, 47 (3), I 36- 145.

SKINNER,W. (1974). The focused factory. Harvard Business Review, II3-I2I.

SLACK, N., Lewis, M. (2008). Operations Strategy. Pearson Education, Essex.

SNOW, C., Hrebiniak, L. (1980). Strategy, distinctive competence, and organizational performance. Administrative Science Quarterly, 25 (2), 317-336.
STAMP, G. (198I). Levels And Types Of Managerial Capability. Journal of Management Studies, 18 (3), 277-298.

SRI, (20II). Sunnybrook Research Institute. Spinoff Companies \& Success Stories. Available from: $<$ http://sunnybrook.ca/research/content/?page=sri_comm spinoff $>$. Accessed in Jan, 23.

TAYLOR, F. (I9II). Princípios de Administração Científica. 3 ed. São Paulo:Atlas, brazilian translation in 1957.

TEECE, D. (1986). Profiting from technological innovation. Research Policy, I5 (6), 285- 305.

TEECE, D. (2006). Reflections on Profiting from Innovation. Research Policy, 35, (8), II3I-II 46.

TEECE, D., Rumelt, R., Dosi, G., Winter, S. (1994). Understanding corporate coherence:Theory and evidence. Journal of Economic Behavior and Organization, 23 (I), I - 30.

WANG, C.-H., Lu, I.-Y., and Chen, C.-B. (2008). Evaluating firm technological innovation capability under uncertainty. Technovation, 28(6), 349-363.

WARD, P., McCreery, J., Ritzman, L., Sharma, D. (1998). Competitive priorities in operations management. Decisions Science, 29 (4), 1035-1046.

WESTPHAL, L.E., Kim, L., Dahlman, C.J. (1985). Reflections on the Republic of Korea's acquisition of technological capability. In: Rosenberg, N., Frischtak, C. International technology transfer: concepts, measures, and comparisons. Praeger, New York.

WHITLEY, R. (1989). On the nature of managerial tasks and skills: their distinguishing characteristics and organization. Journal of Managerial Studies, 26, 209-224.

WILLIAMSON, O. (1985). The Economic Institutions of Capitalism. Free Press, New York. 450p.

WILLIAMSON, O. (1999). Strategic research: governance and competence. Strategic Management Journal, 20 (I2), 1087-II08.

WINTER, S. (1991). On Coase, Competence, and the Corporation, In:Williamson, O. E.,Winter, S. (Eds.). The Nature of the Firm: Origins, Evolution, and Development. Oxford University Press, Oxford, 179- 195. 
YAM, R.; Lo, W.; Tang, E; Lau, A. (20I I). Analysis of sources of innovation, technological innovation capabilities, and performance: An empirical study of Hong Kong manufacturing industries. Research Policy, 40 (3), 737-747.

ZHANG, S., Sood, S. (2002). "Deep" and "Surface" cues: Brand extension evaluations by children and adults. Journal of Consumer Research, 29 (I), |29-I4I.

ZHOU, K.Z., Wu, F. (20I0). Technological capability, strategic flexibility, and product innovation. Strategic Management Journal, 3I, 547-56I.

ZAWISLAK, P.A., Larentis F., Machado C. and Andrade, A. (2009). Firm's Innovation Expectation, Potential and Actions: Impressions on the Japanese Videogame Console Market. Journal of Technology Management \& Innovation, 4 (4), 69-8I. 
J.Technol. Manag. Innov. 2012,Volume 7, Issue 2

ISSN: 07I8-2724. (http://www.jotmi.org)

Journal of Technology Management \& Innovation @ Universidad Alberto Hurtado, Facultad de Economía y Negocios. 